\title{
Do Management Earnings Forecasts Incorporate Information in Earnings' Components? Evidence from the Tunisian Context
}

\author{
Fatma Boubakri \\ Assistant Professor \\ Accounting department, College of Business \\ King Khalid University (KSA) \\ $\&$ \\ Accounting and Finance department \\ High School of Economic and Commercial Sciences (ESSEC) \\ University of Tunis
}

\begin{abstract}
The aim of this paper is to explain the management earnings forecast errors of Tunisian listed firms and examine whether the management earnings forecasts reflect fully the implications of the two components accruals and cash flows of current earnings for the future earnings. Using a sample of Tunisian non-financial firms over the period 2009-2018, the Hausman test result advocates choosing the fixed effects models to determine which information from mandatory disclosures, can explain the management earnings forecast errors in listed Tunisian firms. Our results indicate a negative and significant association between management earnings forecast errors and cash flows component but the effect of the accruals component on management forecast errors is not statistically significant. These results show that managers estimate correctly the accruals persistence but underestimate the cash flows persistence.
\end{abstract}

Keywords Management earnings forecasts, Forecast errors, Accruals, Cash flows.

\section{Introduction}

The literature on voluntary disclosure assumed that managers have superior information to outside investors on their firms' expected future performance. Through voluntary disclosure, managers try to communicate their superior knowledge to investors (Healy \& Palepu, 2001) and assist decision-makers who are relying on accounting information provided by the firms (Dastgir et al., 2007). In fact, voluntary disclosure is an important way for managers to keep investors and financial markets informed of their firms' performance (Healy \& Palepu, 2001). A good information infrastructure attracts foreign investors, stimulates capital inflows, contributes to the smooth functioning of the stock markets, and provides the impetus for economic growth in the developing countries (Kang \& Gray, 2011; Diouani \& Khlif, 2013).

Management forecasts are a very important voluntary disclosure. Many studies in the literature show that these forecasts are very informative and have mainly highlighted the importance of the forecasts provided by the managers of listed firms for investors. These studies demonstrate that the management forecasts are superior to analysts' forecasts as a proxy for the market expectations of earnings (Ajinkya \& Gift, 1984; Waymire, 1984 \& 1986), lead to a revision of investors' earnings expectations (Baginski et al., 1993) and significantly influence security prices (Kothari, 2001; Healy \& Palepu, 2001). Wang et al. (2015) added that, when managers anticipate that the firm's performance may fluctuate or deviate significantly from preliminary expectations they release earnings forecasts.

Given the fact that management forecasts are an important input for investment decisions and the reliability of management earnings forecasts will be of important concern to investors, the question of whether the management earnings forecasts contain errors that can be explained based on properties of earnings' components, is of great importance. The existing body of academic research investigates the properties of earnings' components in various ways. For example, a study by Sloan (1996) on if the stock prices fully reflect information in accruals and cash flows about future earnings, found that disaggregating and differentially weighting the accruals and cash flow components of earnings provide better forecasts of future earnings and the investors tend to overestimate the persistence of accruals and underestimate the persistence of cash flows. However, Collins et al. (2003) show that the sophisticated financial statement users reveal a better understanding of the implications of accruals for the future earnings and exhibit a less accruals mispricing. Others suggest that although sophisticated financial statement users have a better understanding of accruals than naive users, they do not anticipate fully the effect of the lower persistence of accruals on future earnings (Bradshaw et al., 2001; Barth \& Hutton, 2004). 
In the same vein, Gong et al. (2009) report that, despite the fact that the managers presumably possess superior private information about their firms' business prospects and accruals-generation processes, in an uncertain operating environment; their knowledge about their firms' business prospects is imperfect, which can lead to misestimate the accruals persistence and their implications for earnings forecasts. So, the informational superiority of managers about their firms' business prospects and accruals-generation processes, do not necessarily lead to the management earnings forecasts free from errors.

Research in accounting has deeply analyzed the voluntary disclosure and the management earnings forecasts in developed capital markets, but this issue has not been sufficiently examined on emerging stock markets. Besides, the results of studies from developed capital markets cannot be generalized, due to differences in political, economic, legal and social factors (Md Zaini et al., 2018). Also, previous studies on emerging economies reported that the quality of voluntary disclosure is low (Chau and Gray, 2010; Siregar and Siagian, 2013).

Tunisian capital market is considered as an emerging stock market and several studies have shown that the level of voluntary disclosure in the annual reports of Tunisian companies listed on the Tunisian Stock Exchange remains low (Turki \& Omri 2008; Diouani \& Khlif 2013).

By highlighting the centrality of the manager, especially in emerging countries, this article proposes to study the voluntary disclosure in Tunisian context by examining the management earnings forecasts. This study investigates the relation between management earnings forecast errors and the two earnings' components, accruals and cash flows. When referring to studies in the Tunisian context, we note that much of voluntary disclosure research narrowly focuses on either the determinants of voluntary disclosure (Jouirou \& Chenguel, 2014; Boudiche, 2013) or the effect of audit quality on the extent of voluntary disclosure (Ahmadi \& Bouri, 2019). Consequently, it appears that some important concerns about the quality of management forecasts are ignored. Furthermore, notwithstanding that management earnings forecasts are already examined in other contexts (UK, USA, France and other), no empirical studies on the interaction between management earnings forecasts errors and the properties of earnings' components have been conducted in Tunisia context. The purpose of this study is to examine whether managers appreciate fully the implications of current year earnings' components, accruals and cash flows, for subsequent year earnings. In other words, we examine the association between errors in management forecasts of subsequent year earnings and current year earnings' components in Tunisian context.

Unlike the developed markets, the Tunisian financial market is an emerging and very small market. Also, emerging markets have become the focus of international companies, personal and individual investors because of their economic growth, potential investment benefits and promise of substantial returns to the shareholders (Millar et al., 2005).This paper makes three contributions to the existing literature. First, prior research has largely focused on the relation between management earnings forecast errors and accruals component in developed markets. Our study extends prior research by examining the relation between the management earnings forecast errors and the two earnings' components, accruals and cash flows. We add to this literature by showing that management earnings forecasts contain predictable errors in relation to historically reported cash flows. We demonstrate that managers even though they have superior specific information about their firms and probably have a superior ability to predict future earnings changes, they fail to fully incorporate the properties of the cash flow component of earnings and do not incorporate information contained in cash flows into their forecasts but they fully incorporate the information in current year's accruals. Second, in contrast to the previous studies that have limited the accruals to working capital accruals and omitted many accruals relating to non-current operating accruals and financial accruals, we use a comprehensive measure of accruals defined by Richardson et al. (2005). Third, we examine whether the factors explaining the managers' forecast errors raised in the literature about developed markets context like the U.S. market, may explain the managers' forecast errors in the context of an emerging and small market such as the Tunisian market.

The remainder of the paper is organized as follows. Section 2 describes the Tunisian institutional background. Section 3 presents literature review and develops our research hypothesis. Section 4 describes our methodology and data. Section 5 reports and discusses the empirical results. Section 6 concludes the study.

\section{The Tunisian institutional background}

In Tunisia, since the nineties many reforms were implemented to enhance the capital market activity and to contribute to its development. The privatization of state-owned enterprises has also favored the expansion of this market (Diouani \& Khlif, 2013). In recent years, regulators have also forced companies to provide more information. Article 3 (new) of Law No. 2005-96 of 18 October 2005 and Article 44 (new) of the Decree of the Minister of Finance of 17 September 2008 advocate several points of information for Tunisian public offering companies. They mainly include a presentation of operating results, their expected evolution and changes in the methods of preparing and presenting the financial statements. Nevertheless, the leaders are not obliged to respect this model of activity report and its respect depends on the will of the managers (Diouani \& Khlif, 2013). 
In addition, several studies have shown that the level of voluntary disclosure in the Tunisian companies' reports remains low (Turki \& Omri, 2008; Diouani \& Khlif, 2013). The Tunisian managers have a wide margin of discretion regarding the communication of information.

\section{Literature Review and hypothesis development}

In the literature, many explanatory factors of forecast errors have been identified. In this paper we focus primarily on the components accruals and cash flows of current earnings and we include control variables that can affect management earnings forecast errors.

\subsection{Accruals}

Accruals are fundamental to financial reporting and represent a key aspect of accounting information provided by the firms (Richardson et al., 2005; Gong et al., 2009). They are frequently based on assumptions and estimates. So they involve a great degree of managerial subjectivity. The managers can intentionally (managerial opportunism) or unintentionally (e. g., over- stock inventory, under- estimate receivable allowances) misestimate accruals (Richardson et al., 2005) and consequently the subsequent earnings. Dechow \& Dichev (2002) argue that the quality of earnings is decreasing in the magnitude of estimation error in accruals.

Previous studies document that investors and financial analysts do not fully incorporate the implications of accruals for future earnings (Sloan, 1996; Bradshaw et al., 2001; Richardson et al., 2005). Unlike investors and financial analysts, managers, as corporate decision makers and financial information suppliers, seemingly possess superior knowledge of the earnings process of their firms and more particularly more information about their firms' business prospects and accruals-generation processes and accordingly about accruals quality (Gong et al., 2009; $\mathrm{Xu}, 2009$ ). Despite the fact that managers likely have the most inclusive firm-specific information set on factors underlying the persistence of accruals, the human inference and estimation, in general, is subject to systematic biases (Hilary et al., 2016).

Managers must make difficult decisions and can commit errors in evaluating the future performance that affect the persistence of accruals and likely misestimate accrual reversals (Xu, 2010). The misestimate accrual reversals can be explained by the managers' imperfect evaluations of their future economic benefits essentially for firms operating in a more uncertain business environment (Gong et al., 2009). In fact, the managers' lack of knowledge about their firms' business environment (such as unpredictable changes in market demand and competitor strategies) engenders substantial judgment errors in managers' assessments of business prospects and generates misestimated accruals and biases in managers' earnings forecasts. The errors embedded in managers' business assessments are likely to manifest in both management earnings forecasts and accruals (Gong et al., 2009). The positive association between management forecast errors and accruals can arise from managerial judgmental errors. On the other hand, past performance leads to managerial over-optimism and individuals are over-optimism in general, and particularly so regarding the effect of their own action (Hilary et al., 2016). A series of good performance lead managers to under-estimate the role of random noise and over-attribute success to their own actions.

If so, the management earnings forecasts can contain unintentional errors underlying the misestimate of accruals. Furthermore, because of the informational advantage of managers over outside investors, it is very difficult for the latter to judge the reliability of the management earnings forecasts, and they can be easily misled by managers with opportunistic incentives (Wang et al., 2015). Various incentives can motivate managers to manipulate accruals and bias their earnings forecasts. Consequently, management earnings forecasts can probably be affected by managerial opportunism. Some studies identify some potential sources of incentives to mislead investors such as reduce litigation risk, external financing, obtain private benefits (Xu, 2009; Rogers \& Stocken, 2005; Gong et al., 2009). So, the accrual estimation errors could be a result of intentional errors.

For our purposes, we do not attempt to separate intentional estimation errors from unintentional errors because both imply low-quality accruals and can explain management earnings forecast errors.

To empirically test this assumption, we examine whether errors in management forecasts of subsequent year earnings (defined as the difference between management forecasted earnings and actual earnings scaled by share price) are significantly and positively associated with current year accruals.

H1. There is a positive and significant association between management earnings forecast errors and accruals.

\subsection{Cash-flows}

Cash flows from operations provide a key metric in assessing a firm's ability to generate cash from internal operations and remain viable (Luo, 2008). The persistence of cash flows into the future is an essential attribute for prediction (Cheng \& Hollie, 2008). The usefulness of cash flow information has been documented by many studies showing their greater persistence over accruals (Sloan, 1996 ; Richardson et al., 2005; Cheng \& Hollie, 2008). 
Sloan (1996) reports that investors fail to distinguish fully between the different properties of the accrual and cash flow components of earnings and demonstrate that the information content of these two components is systematically different. Accruals component involves a greater degree of subjectivity and the cash flow component as a measure of performance is less subject to distortion than is the accruals (Bernstein, 1993). Following Sloan (1996), numerous studies show that the cash flow component of earnings is more persistent than the accrual component and the stock market overvalues the persistence of accruals and underestimates the persistence of cash flows (Drake et al., 2009; Pincus et al., 2007; Chan et al., 2006; Xie, 2001).

While cash flow is more objectively measured than accruals, it is still subject to misstatement (Dechow et al., 2008).

Some research concerns that cash flows are as vulnerable to manipulation within accounting rules as accruals (Dechow et al., 2008; Graham et al., 2005). Luo (2008) suggests that cash flows can distort investor perception of a firm's ability to generate future profits and potentially mislead investors in assessing future prospectus. In fact, the persistence of accruals and cash flows is affected differently by the same activities (Cheng \& Hollie, 2008). Following the example of Luo (2008) for credit sale transactions, any collection from customers will decrease the balance of accounts receivable and increase cash flows from operations. Managers by choosing a cheaper way of financing and to collect cash much faster can decide to discretionarily securitize or sell receivables all at once. This method can temporarily increase the current operating cash flows but its persistence in the future is not guaranteed. Indeed, a significant amount of such cash inflows can distort the earnings forecasts if these discretionary cash flows do not recur in the future. These results support the hypothesis that managers may misinterpret the persistence of the cash flow component of earnings, causing biased management earnings forecasts.

To empirically test this assumption, we examine whether errors in management forecasts of subsequent year earnings (defined as the difference between management forecasted earnings and actual earnings scaled by share price) are significantly and negatively associated with current year cash flows.

H2. There is a negative and significant association between management earnings forecast errors and cash flows.

\subsection{Control variables}

In addition to accruals and cash-flows we model management earnings forecast errors on variables that control for other factors that seem likely to explain part of the variation in management forecast errors. Therefore, we include firm size and book-to-market ratio as control variables in our model.

\subsubsection{Firm size}

Previous studies consider firm size as a potential factor affecting management earnings forecast quality. Some studies (Atiase, 1985; Freeman, 1987) have shown that the environmental information of the firm is related to its size. In particular, there is a broader and richer information available on the activities of larger firms vis-à-vis smaller and the activities of larger firms are monitored more closely by greater number of traders and professional analysts, which could limit the earnings management (Bozec, 2008). Larger firms are usually more diversified and likely to have more influence over their market settings than the smaller firms (Chen et al., 2001). They are more likely to make voluntary disclosures (Meek et al., 1995; Baginski et al., 2002) and they have better information forecasting systems (Chan et al., 1996). The managers of large firms are assumed to have a better understanding of their market and, moreover, they are able to spend more resources to make their forecasts, thereby resulting in more accurate earnings forecast than smaller firms (Firth \& Smith, 1992). Hagerman and Ruland (1979) show that the large firms' management forecasts tend to be more accurate than the small firms' management forecasts given that they are more diversified and can take environment volatility. Collins et al. (1987) find that the absolute forecast errors vary inversely with the size of the firm. So the management forecast errors are supposed to decrease with the size of the firm. In the same vein, Dechow and Dichev (2002) find that accrual quality is positively related to firm size.

On the other side, larger firms' managers may also make inaccurate earnings forecast due to accounting complexity. A number of studies (Firth \& Smith, 1992; Baginski \& Hassell, 1997) report a positive relationship between firm size and forecast error and reveal that forecast among smaller firms are more accurate than of those for larger firms. A possible explanation is that firm size proxies for amount of public information and more information about large firms is produced by parties external to the firm (Baginski \& Hassell, 1997). Another explanation is that the market is more tolerant of errors from larger firms than from smaller one and thus the smaller firms' managers might be incited to provide more accurate earnings forecast (Chan et al., 1996).

\subsubsection{Book to market ratio}

Bédard et al. (2008) show that the forecast errors are affected by firm's risk. Fama and French (1992) consider the book-to-market ratio $(\mathrm{B} / \mathrm{M})$ as proxy of risk. It seems reasonable to think that firm with higher $\mathrm{B} / \mathrm{M}$ ratio might 
exhibit more volatility in their earnings than firms with lower $\mathrm{B} / \mathrm{M}$ ratio and earnings forecasting is likely to be more difficult. Moreover, the valuation of high-growth firms largely depends on expected future cash flows, intensifying market demand and public review for information disclosures (Gong et al., 2009). Therefore, we include $\mathrm{B} / \mathrm{M}$ ratio as a control variable.

\section{Research design}

\subsection{Sample}

The initial sample includes Tunisian firms listed on the Tunisian Stock Exchange for 12-year period 2007-2018. It consists of 580 firm-year observations. Since regressions rely on change in variables the final sample is from 2009 to 2018. The sample periods starts in 2009 and not before because the number of management earnings forecasts prior to 2009 is substantially lower.

We exclude from the sample financial firms (banks and insurance companies) because of particularities in the accruals for this type of firms. We next eliminate firm-year observations with insufficient data to compute the principal variables used in our tests and firms with less than three observations. The final sample consists of 155 firm-year observations with available management earnings forecasts, stock prices and financial statement data.

We collect our data from different sources especially annual reports and web sites. Accounting data are handcollected from the firms' financial statements available on the Tunisian Financial Market Council website, while market data are hand-collected from the Tunisian Stock Exchange website. When a firm issues more than one forecast for a given year, we retain only the last forecast. The Tunisian managers make earnings forecasts with a longer horizon from 1 to 5 years.

\subsection{Regression models}

We use the following regression equations to test our hypothesis about management forecast errors:

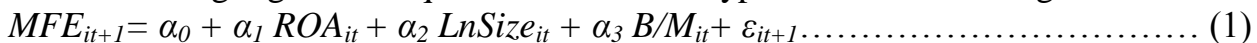

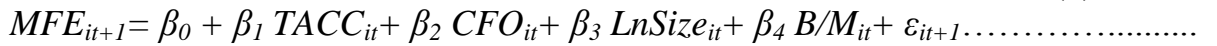

Where, $\mathrm{MFE}_{\mathrm{it}+1}$ is the management earnings forecast errors for firm $\mathrm{i}$ and year $\mathrm{t}+1, \mathrm{ROA}_{\mathrm{it}}$ is the return on assets of firm $\mathrm{i}$ in year $\mathrm{t}, \mathrm{TACC}_{\mathrm{it}}$ is the total accruals from the balance sheet approach of firm $\mathrm{i}$ in year $\mathrm{t}, \mathrm{CFO}_{\mathrm{it}}$ is the operating cash flows of firm $i$ in year $t, \mathrm{LnSize}_{i t}$ is the size of firm $\mathrm{i}$ in year $\mathrm{t}, \mathrm{B} / \mathrm{M}_{\mathrm{it}}$ is the book-to-market ratio of firm $\mathrm{i}$ in year $\mathrm{t}$.

Sloan (1996) defines accruals as the change in non-cash working capital less depreciation. However, this definition of accruals omits many accruals and deferrals relating to non-current operating assets and liabilities. Subsequent research by Fairfield et al. (2003) and Richardson et al. (2005) extends Sloan's measure to incorporate all non-cash operating assets and liabilities. Richardson et al. (2005) argue that the extended measure provides a more comprehensive measure of accruals and sustaining evidence. Following Richardson et al. (2005), we use a comprehensive definition of accruals.

\begin{tabular}{|c|c|}
\hline $\begin{array}{l}\text { Variables } \\
\text { (Hypothesis) }\end{array}$ & Definitions \\
\hline MFE & $\begin{array}{l}\mathrm{MFE}_{\mathrm{it+1}}=[\text { Management earnings forecasts per share } \mathrm{i} \text { for year } \mathrm{t}+1-\text { Actual } \\
\text { earnings per share } \mathrm{i} \text { for year } \mathrm{t}+1] / \text { closing share price } \mathrm{i} \text { at the end of year } \mathrm{t} \text {; }\end{array}$ \\
\hline ROA & $\mathrm{ROA}_{\mathrm{it}}=$ Net income per share i for year ${ }_{\mathrm{t}} / \mathrm{Average} \mathrm{total} \mathrm{assets}_{\text {it }}$ \\
\hline $\begin{array}{l}\text { TACC } \\
\left(H_{l}: \beta_{1}>0\right)\end{array}$ & TACC $_{\text {it }}=\left[\Delta\right.$ Non-cash assets ${ }_{i t}-\Delta$ Liabilities $\left._{i t}\right] /$ Average total assets it $_{\text {it }}$ \\
\hline $\begin{array}{l}\mathrm{CFO} \\
\left(H_{2}: \beta_{2}<0\right)\end{array}$ & 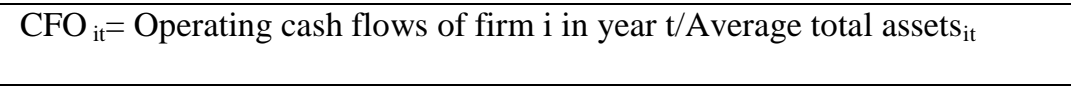 \\
\hline LnSize & $\begin{array}{l}\text { LnSize }_{\text {it }} \text { The natural logarithm of the firm's market value of equity i at the } \\
\text { end of the year } t \text {; }\end{array}$ \\
\hline $\mathrm{B} / \mathrm{M}$ & $\begin{array}{l}\mathrm{B} / \mathrm{M}_{\mathrm{it}}=\text { Book value of equity } \mathrm{i} \text { at the end of the year } \mathrm{t} / \text { Market value of } \\
\text { equity } \mathrm{i} \text { at the end of the year } \mathrm{t} \text {. }\end{array}$ \\
\hline
\end{tabular}

In $H 1$, we predict a positive and significant relation between management earnings forecast errors and accruals, i.e., $\beta_{1}>0$. The second hypothesis $H 2$ supposes that the relation between management earnings forecast errors and cash flows is negative and significant, i.e., $\beta_{2}<0$.

\section{Empirical results}

\subsection{Descriptive Statistics}

Panel A of Table 2 reports the descriptive statistics for our sample of 155 observations. We find that the mean 
management forecast errors $(M F E)$ is positive $(0,260)$, showing optimistic biases in management earnings forecasts. This finding is consistent with prior studies (e.g., Gong et al., 2009; Xu, 2009; Choi \& Ziebart, 2004) who report that long-term management forecasts are optimistically biased. As shown in table 2, the mean total accruals $(T A C C)$ and cash flows $(C F O)$ are -0.018 and 0,054 respectively which is consistent with prior findings that total accruals, on average, are negative and cash flows are positive (Gong et al., 2009; Xu, 2010; Sloan, 1996).

Panel B of Table 2 provides pairwise correlations between variables in Equations (1) and (2). We find that management forecast errors are positively and weakly correlated with total accruals (0.006) and negatively correlated with cash flows $(-0,020)$.

In addition, the correlations between exogenous variables reported in Table 2 are less than the 0.8 (limit fixed by Kennedy, 1985), suggesting that multicollinearity is unlikely to be a problem.

Table 2 Descriptive statistics and correlation matrix

\begin{tabular}{|c|c|c|c|c|c|c|c|}
\hline \multicolumn{8}{|c|}{ Panel A: Descriptive statistics } \\
\hline Variables & & Mean & & Std. Dev & Maximum & & Minimum \\
\hline $\mathrm{MFE}_{\mathrm{it}+1}$ & & 0,260 & & 0,955 & 5,377 & & $-3,182$ \\
\hline $\mathrm{ROA}_{\mathrm{it}}$ & & 0,034 & & 0.068 & 0,224 & & $-0,199$ \\
\hline TACC $_{\text {it }}$ & & $-0,018$ & & 0,293 & 2,039 & & $-1,647$ \\
\hline $\mathrm{CFO}_{\text {it }}$ & & 0,054 & & 0,180 & 0,601 & & $-0,683$ \\
\hline $\mathrm{B} / \mathrm{M}_{\mathrm{it}}$ & & 1,135 & & 2,067 & 14,204 & & $-7,238$ \\
\hline LnSize $_{\text {it }}$ & & 17,394 & & 1,081 & 21,161 & & 13.634 \\
\hline \multicolumn{8}{|c|}{ Panel B: Correlation matrix-Pearson } \\
\hline & $\mathrm{MFE}_{\mathrm{it}+1}$ & & $\mathrm{ROA}_{\text {it }}$ & TACC $_{\text {it }}$ & $\mathrm{CFO}_{\text {it }}$ & LnSize $_{\text {it }}$ & $\mathrm{B} / \mathrm{M}_{\mathrm{it}}$ \\
\hline $\mathrm{MFE}_{\mathrm{it}+1}$ & 1 & & & & & & \\
\hline $\mathrm{ROA}_{\mathrm{it}}$ & $-0,124$ & & 1 & & & & \\
\hline TACC $_{\text {it }}$ & 0,006 & & $0,218^{* * * *}$ & 1 & & & \\
\hline $\mathrm{CFO}_{\text {it }}$ & $-0,020$ & & $0,226^{* * * *}$ & $-0,013$ & 1 & & \\
\hline LnSize $_{\text {it }}$ & $-0,179^{* *}$ & & $0,301^{\text {*** }}$ & 0,035 & $-0,042$ & 1 & \\
\hline $\mathrm{B} / \mathrm{M}_{\mathrm{it}}$ & 0,098 & & $-0,082$ & 0,040 & $0,280^{* * * *}$ & $-0,341^{* * *}$ & 1 \\
\hline
\end{tabular}

Notes: **, ***: Denote significance at the 0,05 and 0.01 level, respectively.

\subsection{Empirical analysis}

Table 3 presents the results of the regression models (1) and (2) using unbalanced panel data. The Hausman test result advocates choosing the fixed effects model.

\section{Table 3 -Regression results of Management Earnings Forecast Errors on Earnings Components}

Panel A:

$\mathrm{MFE}_{\mathrm{it}+1}=\alpha_{0}+\alpha_{1} \mathrm{ROA}_{\mathrm{it}}+\alpha_{2}$ LnSize $_{\mathrm{it}}+\alpha_{3} \mathrm{~B} / \mathrm{M}_{\mathrm{it}}+\varepsilon_{\mathrm{it}+1}$

\begin{tabular}{llllll}
\hline & Intercept & ROA & LnSize & B/M & F-Stat \\
\hline Estimated coefficient & 0.425 & $-5,378^{* * * *}$ & $-0,003$ & $0,070^{* *}$ & $5.32^{* * * *}$ \\
(t-stat) & $(0.21)$ & $(-3.33)$ & $(-0.03)$ & $(1.61)$ &
\end{tabular}

\begin{tabular}{|c|c|c|c|c|c|c|}
\hline $\begin{array}{l}\text { Fisher test: } \\
\text { Hausman test: }\end{array}$ & $\begin{array}{r}\mathrm{F}(30,12 \\
\text { chi2(3) }\end{array}$ & $\begin{array}{l}=4,25 \\
6,86\end{array}$ & $\begin{array}{l}\mathrm{Pr} \\
\mathrm{Pr}\end{array}$ & $\begin{array}{l}=0,000 \\
\text { ii } 2=0,07\end{array}$ & & \\
\hline $\begin{array}{l}\text { Panel B: } \\
\text { MFE }_{\mathrm{it}+1}=\beta_{0}+\beta_{1} \mathrm{TAC}\end{array}$ & 2 & $\mathrm{nSiz}$ & $\mathrm{B} / \mathrm{M}_{\mathrm{it}}+\varepsilon_{\mathrm{i}}$ & & & \\
\hline & Intercept & TACC & CFO & LnSize & $\mathrm{B} / \mathrm{M}$ & F-Stat \\
\hline $\begin{array}{l}\text { Estimated coefficient } \\
\text { (t-stat) }\end{array}$ & $\begin{array}{l}1.719 \\
(0,83)\end{array}$ & $\begin{array}{l}-0,121 \\
(-0,55)\end{array}$ & $\begin{array}{l}-0,929^{*} \\
(-2,02)\end{array}$ & $\begin{array}{l}-0,087 \\
(-0,74)\end{array}$ & $\begin{array}{l}0,083^{*} \\
(1,81)\end{array}$ & $2,23^{*}$ \\
\hline $\begin{array}{l}\text { Fisher test: } \\
\text { Hausman test: }\end{array}$ & $\begin{array}{r}\mathrm{F}(30,12 \\
\text { chi2(4) }\end{array}$ & $\begin{array}{l}=3,83 \\
27,19\end{array}$ & & $\begin{array}{l}=0,000 \\
\text { chi } 2=0,0\end{array}$ & & \\
\hline
\end{tabular}

Notes: *,**,***: Denote significance at the 0,$1 ; 0.05$ and 0.01 level, respectively.

As shown in Table 3, panel A, the coefficient on $\mathrm{ROA}_{\mathrm{it}}$ is significantly negative at $1 \%(-5,378)$, suggesting that the management earnings forecasts contain greater pessimistic errors when ROA are relatively high. Managers underestimate the implications of current earnings information when forecasting future earnings.

According to Hilary et al. (2016), the managers of firms that have experienced recent success are more likely to subsequently issue optimistic forecasts. So the mangers that issue pessimistic forecasts are likely to be the managers of firms that have experienced recent bad experiences. 
Panel B, Table 3 provides my results of analyses of $H 1$, which posits a positive and significant relation between accruals and management forecast errors. The coefficient on $\operatorname{TACC}_{\text {it }}(-0,121)$ is negative and not statistically significant, indicating that the managers anticipate correctly the persistence of accruals component. This result rejects the first hypothesis $H I$ that the association between management forecast errors and accruals is positive and significant. Not consistent with prior findings (Gong et al., 2009; Xu, 2010), Tunisian managers appear to incorporate fully into their forecasts the accrual reversals. This result suggests that management earnings forecasts may be sufficiently informative to reduce substantially or even eliminate accrual mispricing.

The coefficient on $\mathrm{CFO}_{\text {it }}(-0,929)$ is significantly negative at $5 \%$, supporting $\mathrm{H} 2$ that the association between management forecast errors and cash flow is negative and significant and indicating that the managers fail to efficiently incorporate information on cash flows persistence into their earnings forecasts. The managers underestimate cash flows reversals, then forecast errors will be more negative for firms with higher cash flows. The management forecasts are relatively more pessimistic following periods of high cash flows. This result indicates either that managers irrationally underestimate cash flows information in their earnings forecasts or that managers fully understand the future implications of the cash flows persistence but intentionally issue forecasts that are pessimistically biased. The negative relationship between management forecast errors and the earnings is attributed to the cash flow component. Our results corroborate those of Pincus et al. (2007) about investors forecasts which show that CFO are underweighted in a large number of countries where accruals are not overweighted and they conjecture the underweighting of CFO to the belief by investors that earnings management occurs in these countries through the structure of transactions rather than the manipulation of accruals.

Contrary to our expectation, firm size is not significant. Several prior studies (El-Rajabi \& Gunasekaran, 2006; Ajinkya et al., 2005), generate similar evidence. In addition, we document a significantly positive coefficient on $\mathrm{B} / \mathrm{M}$, showing that earnings forecasting tend to be more conservative in high-growth firms.

\section{Conclusion}

The study conducted focuses on management earnings forecast errors. We examine the association between errors in management forecasts of subsequent year earnings and current year earnings' components in Tunisian context. In the Tunisian company, the voluntary offer of information is strongly dependent on the free choice of the manager and his attitude.

This study documents that after controlling for firm size and B/M, managers do not fully reflect the information in the earnings' components. Managers tend to forecast subsequent year earnings more pessimistically when current year cash flows are relatively high but they fully incorporate the information in current year's accruals into their forecasts of the subsequent year's earnings. The negative relationship between management forecast errors and the current earnings is attributed to the cash flow component. Our study is the first to examine the relation between the two components of earnings- accruals and cash flows- and management earnings forecast errors in the Tunisian context and show that managers misestimated only the persistence of the cash flows component.

We contribute to management earnings forecasts literature by demonstrating a predictable bias in management earnings forecasts based on historically reported cash flows and an insignificant effect of accruals on management earnings forecasts. Most studies have focused on the accruals component of earnings and have shown that management misestimated their persistence in the future. Our findings warn investors to carefully evaluate the management earnings forecasts and the two components of current earnings -accruals and cash flows- when forming their earnings forecasts.

However present study also subjects to some limitations. First, the number of observations is limited because of the small number of firms listed on the Tunisian Stock Exchange and not all Tunisian firms voluntarily issue earnings forecasts. Second, our study examines voluntary disclosure under the context of management earnings forecasts but we do not examine voluntary disclosure under the context of management cash flow forecasts. So, the management cash flow forecasts merit to be examined.

This paper, however, raises some questions, which may provide opportunities for future research. First, the reasons about why managers tend to underestimate the persistence of the cash flows component and estimate correctly the accruals persistence are not yet explored. Following Xu (2009) the answer to this question requires better knowledge of the costs and incentives that drive managers' forecast behavior. Second, according to Luo (2008), the estimation of cash flow components is subject to bias or errors. We then examine whether the managers misestimate all operating cash flows components persistence into their earnings forecasts. 


\section{References}

Ahmadi, A., \& Bouri, A. (2019). The Effect of Audit Quality on the Extent of Voluntary Disclosure: Companies Listed in the Tunisian Stock Exchange. Journal of the Knowledge Economy, vol. 10(1), pp.59-73. https://doi.org/10.1007/s13132-016-0444-y

Ajinkya, B., \& Gift. M. (1984). Corporate managers' earnings forecasts and symmetrical adjustments of market expectations. Journal of Accounting Research, 22(2), pp.425-444. DOI: 10.2307/2490657

Ajinkya, B., Bhojraj, S., \& Sengupta, P. (2005). The association between outside directors, institutional investors and the properties of management earnings forecasts. Journal of Accounting Research, 43(3), 343-376. https://doi.org/10.1111/j.1475-679x.2005.00174.x

Atiase, R. K. (1985). Predisclosure information, firm capitalization, and security price behavior around earnings announcements. Journal of Accounting Research, 23(1), 21-36. DOI: 10.2307/2490905

Baginski, S., Conrad, E., \& Hassell, J., (1993). The effects of management forecast precision on equity pricing and on the assessment of earnings uncertainty. The Accounting Review, 68 (4): 913-927.

Baginski, S. P., \& Hassell, J. M. (1997). Determinants of management forecast precision. The Accounting Review, 72(2), 303-312.

Baginski, S. P., Hassell, J. M., \& Kimbrough, M. D. (2002). The Effect of legal environment on voluntary disclosure: Evidence from management earnings forecasts issued in U.S. and Canadian markets. The Accounting Review, 77 (1),25-50. https://doi.org/10.2308/accr.2002.77.1.25

Barth, M. E., \& Hutton, A. P. (2004). Analyst earnings forecast revisions and the pricing of accruals. Review of Accounting Studies, 9(1), 59-96. https://doi.org/10.1023/B:RAST.0000013629.59222.df

Bédard, J., Coulombe, D., \& Courteau, L. (2008). Audit committee, underpricing of IPOs, and accuracy of management earnings forecasts. Corporate governance: An international review, 16(6), 519-535. https://doi.org/10.1111/j.1467-8683.2008.00708.x

Bernstein, L. A. (1993). Financial statement analysis (5th ed.). Homewood, IL: Irwin.

Boudiche, M. (2013). The Determinants of Profit Forecast by Tunisian Companies. Asian Economic and Financial Review, Asian Economic and Social Society, vol. 3(9), pp. 1180-1194.

Bozec, Y. (2008). Ownership concentration, separation of voting rights from cash flow rights, and earnings management: an empirical study in Canada. Canadian Journal of Administrative Sciences, 25(1), i-xv. https://doi.org/10.1002/cjas.52

Bradshaw, M. T., Richardson, S. A., \& Sloan, R. G. (2001). Do analysts and auditors use information in accruals ? Journal of Accounting Research, vol.39 (1), pp.45-74. https://doi.org/10.1111/1475-679X.00003

Chan, A. M. Y., Sit, C. L. K., Tong, M. M. L., Wong, D. C. K. W., \& Chan, R. W. Y. (1996). Possible factors of the accuracy of prospectus earnings forecasts in Hong Kong. The International Journal of Accounting, 31(3), 381-398. https://doi.org/10.1016/S0020-7063(96)90026-6

Chan, H. W-H., Faff, R., Ho, Y. K., \& Ramsay, A. L. (2006). Asymmetric market reactions of growth and value firms with management earnings forecasts. International Review of Finance, 6(1-2), 79 - 97. https://doi.org/10.1111/j.1468-2443.2007.00060.x

Chau, G., \& Gray, S.J. (2010). Family ownership, board independence and voluntary disclosure: Evidence from Hong Kong. Journal of International Accounting, Auditing and Taxation, Vol. 19(2), pp. 93-109. http://dx.doi.org/10.1016/j.intaccaudtax.2010.07.002

Chen, G., Firth, M., \& Krishnan, G. V. ( 2001). Earnings forecast errors in IPO prospectuses and their associations with initial stock returns. Journal of Multinational Financial Management, 11(2), 225-240. https://doi.org/10.1016/S1042-444X(00)00051-7

Cheng, C. S. A., \& Hollie, D. (2008). Do core and non-core cash fows from operations persist differentially in predicting future cash flows? Review of Quantitative Finance and Accounting, 31(1), 29-53. https://doi.org/10.1007/s11156-007-0062-7

Choi, J. H., \& Ziebart, D. A. (2004). Management earnings forecasts and the market's reaction to predicted bias in the forecast. Asia-Pacific Journal of Accounting and Economics, 11(2), 167-192. https://doi.org/10.1080/16081625.2004.10510641

Collins. D. W, Kothari. S. P., \& Rayburn. J. D. (1987). Firm Size and the Information Content of Prices with Respect to Earnings. Journal of Accounting and Economics, 9(2), 111-138. https://doi.org/10.1016/01654101(87)90002-4

Collins, D. W., Gong, G., \& Hribar, P., (2003). investor sophistication and the mispricing of accruals. review of Accounting studies, 8(2), 251-276. https://doi.org/10.1023/A:1024417513085

Dastgir, M., Sajady, S. H., \& Sabet, H., (2007). Factors affecting bias in management earnings forecasts. Journal of social sciences \& humanities of Shiraz University, 26(1), 1-17.

Dechow, P. M., \& Dichev, L. D. (2002). The Quality of accruals and earnings: The role of accrual estimation errors. The Accounting Review, vol. 77(s-1), pp.35-59. https://doi.org/10.2308/accr.2002.77.s-1.35 
Dechow, P. M., Richardson, S. A., \& Sloan, R. G. (2008). The persistence and pricing of the cash component of earnings. Journal of accounting research, 46(3), 537-566. https://doi.org/10.1111/j.1475-679X.2008.00283.x

Diouani, B., \& Khlif, W. (2013). Comportement du dirigeant et décision de divulgation volontaire d'informations : Cas du marché Tunisien, Management International, Volume 17, Number 4, pp. 34-49. DOI: https://doi.org/10.7202/1020668ar

Drake, M. S., Myers, J. N, \& Myers, L. A. (2009). Disclosure quality and the mispricing of accruals and cash flow. Journal of Accounting, Auditing \& Finance, 24(3), 357-384. https://doi.org/10.1177/0148558X0902400303

El-Rajabi, M. T. A, \& Gunasekaran, A. (2006) . The accuracy of earnings forecasts disclosed in the prospectuses of newly formed public companies in Jordan. Managerial Auditing Journal, 21(2), 117 - 131. https://doi.org/10.1108/02686900610639275

Fairfield, p. m., Whisenant, j. s., \& Yohn, t. 1. (2003). the differential persistence of accruals and cash flows for future operating income versus future profitability. Review of Accounting studies, 8(2-3), 221-243. https://doi.org/10.1023/A:1024413412176

Fama, E. F., \& French, K. R. (1992). The Cross-section of expected stock returns. The Journal of Finance, 47(2), 427-465. https://doi.org/10.1111/j.1540-6261.1992.tb04398.x

Firth, M., \& Smith, A., (1992). The Accuracy of profits forecasts in initial public offering prospectuses. Accounting and Business Research, 22(87), 239-247. https://doi.org/10.1080/00014788.1992.9729441

Freeman, R. N. (1987). The association between accounting earnings and security returns for large and small firms. Journal of Accounting and Economics, 9(2), 195-228. https://doi.org/10.1016/0165-4101(87)90005$\mathrm{X}$

Gong, G., Li, L. Y., \& Xie H., (2009). The association between management earnings forecast errors and accruals. The Accounting Review, 84(2), 497-530. https://doi.org/10.2308/accr.2009.84.2.497

Graham, J. R., Harvey, C. R., \& Rajgopal, S. (2005). The economic implications of corporate financial reporting. The Journal of Accounting and Economics, 40(1-3), 3-73. https://doi.org/10.1016/j.jacceco.2005.01.002

Hagerman, R.L., \& Ruland, W. (1979). The accuracy of management forecasts and forecasts of simple alternative models. Journal of Economics and Business, 31(3), 172-179.

Healy, P. M., Palepu, K. G., (2001). Information asymmetry, corporate disclosure, and the capital markets: A review of the empirical disclosure literature. Journal of Accounting and Economics, 31 (1-3), 405-440. https://doi.org/10.1016/S0165-4101(01)00018-0

Hilary, G., Hsu, C., Segal, B., \& Wang, R. (2016). The bright side of managerial over-optimism. Journal of Accounting and Economics, 62(1), 46-64. https://doi.org/10.1016/j.jacceco.2016.04.001

Jouirou, M., \& Chenguel, M. B. (2014). The determinants of voluntary disclosure in Tunisia: A study of the firms listed in the Tunisian stock exchange. Journal of Business and Management Research, 4, 84-95.

Kang, H., \& Gray S. J., (2011). The Content of Voluntary Intangible Asset Disclosures: Evidence from Emerging Market Companies. Journal of International Accounting Research, $\quad 10(1), \quad 109-125 . \quad$ DOI: 10.2308/jiar.2011.10.1.109

Kennedy, P. (1985). A guide to econometrics (2nd ed.). MIT Press, Cambridge.

Kothari, S. P. (2001). Capital markets research in accounting. Journal of Accounting and Economics, 31 (1-3), 105-231. https://doi.org/10.1016/S0165-4101(01)00030-1

Luo, M. (2008). Unusual operating cash flows and stock returns. Journal of accounting and public policy, 27(5), 420-429. https://doi.org/10.1016/j.jaccpubpol.2008.07.004

Md Zaini, S., Samkin, G., Sharma, U., \& Davey, H. (2018). Voluntary disclosure in emerging countries: A literature review. Journal of Accounting in Emerging Economies, 8(1), 29-65. https://doi.org/10.1108/JAEE-08-2016-0069

Meek, G. K., Roberts, C. B., \& Gray S. J. (1995). Factors influencing voluntary annual report disclosures by U.S., U.K. and continental European multinational corporations. Journal of International Business Studies, 26 (3), 555-572. https://doi.org/10.1057/palgrave.jibs.8490186

Millar, C.C., Eldomiaty, T.I., Choi, C.J. \& Hilton, B. (2005). Corporate Governance and Institutional Transparency in Emerging Markets. Journal of Business Ethics, 59(1/2), 163-174. https://doi.org/10.1007/s10551-005$3412-1$

Pincus, M., Rajgopal, S., \& Venkatachalam, M. (2007). The Accrual anomaly: International evidence. The Accounting Review, 82(1), 169-203. https://doi.org/10.2308/accr.2007.82.1.169

Richardson, S. A., Sloan, R. G., Soliman, M. T., \&Tuna, A. I. (2005). accrual reliability, earnings persistence and stock prices. journal of accounting and economics, 39(3), 437-485. https://doi.org/10.1016/j.jacceco.2005.04.005

Rogers, J. L., \& Stocken P. C. (2005). Credibility of management forecasts. The Accounting Review, 80(4), 12331260. https://doi.org/10.2308/accr.2005.80.4.1233 
Siregar, S., \& Siagian, F. (2013). Corporate governance reporting quality, and firm value: evidence from Indonesia. Journal of Accounting in Emerging Economies, 3(1), 4-20. http://dx.doi.org/10.1108/20440831311287673

Sloan, R. G., (1996). do stock prices fully reflect information in accruals and cash flows about future earnings? the accounting review, 71 (3): 289-315.

Turki, A., \& Omri, A. (2008). Nature de propriété et divulgation volontaire des informations dans les entreprises tunisiennes cotées. Gestion 2000, 25 ( 2), 79-99.

Wang, Y., Chen, Y., \& Wang, J. (2015). Management earnings forecasts and analyst forecasts: Evidence from mandatory disclosure system. China Journal of Accounting Research, 8(2), 133-146. https://doi.org/10.1016/j.cjar.2014.09.001

Waymire, G. (1984). Additional evidence on the information content of management earnings forecasts. Journal of Accounting Research, 22 (2), 703-718. DOI: $10.2307 / 2490672$

Waymire, G., (1986). Additional evidence on the accuracy of analyst forecasts before and after voluntary management earnings forecasts. The Accounting Review, 61(1), 129-142.

Xie, H. (2001). The mispricing of abnormal accruals. The Accounting Review, 76(3), 357-373. https://doi.org/10.2308/accr.2001.76.3.357

$\mathrm{Xu}, \mathrm{W}$. (2009). Evidence that management earnings forecasts do not fully incorporate information in prior forecast errors. Journal of Business Finance \& Accounting, 36(7-8), 822-837. https://doi.org/10.1111/j.14685957.2009.02152.x

Xu, W. (2010). Do management earnings forecasts incorporate information in accruals? The Journal of Accounting and Economics, 49(3), 227-246. https://doi.org/10.1016/j.jacceco.2009.11.005 